\title{
Pulmonary Function Tests and Thyroid Hormone Concentrations in Patients with Chronic Obstructive Pulmonary Disease
}

\author{
Oguzhan Okutan $^{a} \quad$ Zafer Kartaloglu $^{a} \quad$ Mehmet Emin Onde ${ }^{b} \quad$ Erkan Bozkanat $^{a}$ \\ Erdogan Kunter ${ }^{a}$ \\ Departments of aPulmonary Diseases and 'bendocrinology, GATA Haydarpasa Training Hospital, Istanbul, Turkey
}

\section{Key Words}

Chronic obstructive pulmonary disease - Thyroid •

Pulmonary function test - Thyroid-stimulating hormone . Free 3,5,3'-triiodothyronine $\cdot$ Free thyroxine

\begin{abstract}
Objective: To evaluate the relationship between pulmonary function tests, arterial blood gases, and thyroid gland functions in patients with chronic obstructive pulmonary disease (COPD). Subjects and Methods: Thirtytwo patients (mean age $64.1 \pm 7.3$ years, range $53-84$ years) with stable COPD (mean duration of disease 11.1 \pm 9.1 years, range $1-30$ years) and 15 healthy control cases participated in the study. Pulmonary function, arterial blood gas, and thyroid hormone concentration were measured, and thyroid ultrasonography and scintigraphy were also performed. Results: The values of the pulmonary function tests (vital capacity, forced vital capacity, forced expiratory volume in $1 \mathrm{~s}$ and peak expiratory flow) and $\mathrm{PaO}_{2}$ were lower in the study than control group ( $p<0.001)$, but the values of $\mathrm{PaCO}_{2}$ and concentration of free 3,5,3'-triiodothyronine $\left(\mathrm{fT}_{3}\right)$ were higher in the study than control group $(p<0.01)$ although thyroid hormone concentrations were within normal limits in all cases. However, there was no difference between the
\end{abstract}

\section{KARGER}

Fax +41613061234

E-Mail karger@karger.ch

www.karger.com (c) 2004 S. Karger AG, Basel

1011-7571/04/0133-0126\$21.00/0

Accessible online at:

www. karger.com/mpp values of thyroid-stimulating hormone and free thyroxine in both the study and control groups and therefore association could not be established between them on the one hand and pulmonary function test and arterial blood gases on the other hand. Only the values of $\mathrm{PaCO}_{2}$ and $\mathrm{fT}_{3}$ were positively associated; all other values were negatively associated with $\mathrm{fT}_{3}$. Conclusion: Changes in pulmonary function tests and arterial blood gases seem to be associated with $\mathrm{fT}_{3}$ concentrations in patients with COPD. Increased respiratory workload could affect thyroid functions.

Copyright $@ 2004$ S. Karger AG, Basel

\section{Introduction}

Chronic obstructive pulmonary disease (COPD) is a major cause of chronic morbidity and mortality throughout the world, leading to years of suffering and premature death from it or its complications [1]. COPD, which may be accompanied by hyperreactivity and may be partially reversible, is characterized by chronic bronchitis or emphysema and progressive airflow obstruction. The severity of airway obstruction in these patients affects the rate of survival [2] and is associated with impairment of thyroid gland function $[3,4]$. As soon as the airway is ob-

Oguzhan Okutan, MD

GATA Camlica Chest Diseases Hospital

TR-81020 Acibadem/Istanbul (Turkey)

Tel +902163257250, Fax +902163257257

E-Mail oguzhanokutan@hotmail.com 
structed, patients with COPD develop hypoxemia and hypercapnia; in cases of chronic hypoxemia various endocrine organs are affected. It was found that hypoxia can produce abnormalities of hypothalamic-pituitary function, but this alteration does not cause any changes in hypothalamic-thyroid axis [5].

COPD patients may need to exert more effort to breathe, thus increasing metabolism. It is not known how these changes affect concentrations of thyroid-stimulating hormone (TSH), free 3,5,3'-triiodothyronine $\left(\mathrm{fT}_{3}\right)$, and free thyroxine $\left(\mathrm{fT}_{4}\right)$. In this study, we evaluated the relationship between pulmonary function tests, arterial blood gases, and thyroid gland functions in patients with COPD.

\section{Subjects and Methods}

\section{Subjects}

Forty-seven subjects participated in this study: 32 patients and 15 controls. The 32 patients were recruited from the outpatient clinic in Camlica Chest Diseases Hospital and had stable stage II COPD according to Global Initiative for Chronic Obstructive Lung Disease [6] criteria. These criteria include the ratio of forced expiratory volume in $1 \mathrm{~s}$ to forced vital capacity $\left(\mathrm{FEV}_{1} / \mathrm{FVC}\right)\left(<70 \%, 30 \% \leq \mathrm{FEV}_{1}\right.$ $<80 \%$ predicted)X, with or without chronic symptoms such as cough, sputum production, dyspnea. Ten cases were stage IIA $(50 \%$ $\leq \mathrm{FEV}_{1}<80 \%$ predicted $)$, and 22 cases were stage $\mathrm{IIB}\left(30 \% \leq \mathrm{FEV}_{1}\right.$ $<50$ predicted). Patients on medication were not excluded, but patients with other respiratory diseases, a known thyroid disease or previous thyroid surgery, any other endocrine system diseases, neuromuscular system diseases, cardiovascular system diseases or collagen tissue diseases were excluded. The patients were not receiving iodine-containing drugs. Seven patients were current smokers, 13 were ex-smokers, and 12 were nonsmokers.

The controls were 15 volunteers ( 9 men and 6 women), who did not receive iodine, theophylline, or steroids.

\section{Study Design}

A clinical history was obtained and a physical examination performed on the patients. In all cases, pulmonary function tests were done in the morning (AS 600 Minato, Osaka, Japan). Vital capacity (VC), FVC, $\mathrm{FEV}_{1}$, peak expiratory flow (PEF) and $\mathrm{FEV}_{1} / \mathrm{VC}$ were recorded. Arterial blood gas analyses (Nova Biomedical, STAT PRO 9, Waltham, Mass., USA) were performed just after pulmonary function tests. Whole blood sample was obtained on the same day and radioimmunoassay (Diagnostic Products Corp., Los Angeles, Calif., USA) was used to determine the concentrations of $\mathrm{TSH}, \mathrm{fT}_{3}$ and $\mathrm{fT}_{4}$.

\section{Statistical Analysis}

Results were expressed as the mean \pm SD. Statistical analysis was performed by Student's t test for comparison of the experimental group and control group. Significance was defined as a $p$ value $<0.05$.

Thyroid Functions and COPD
Table 1. Characteristics of patient and control cases

\begin{tabular}{lll}
\hline Characteristics & Patients & Controls \\
\hline Age, years & $64.1 \pm 7.3(53-84)$ & $61.7 \pm 5.2(48-79)$ \\
Sex & & \\
$\quad$ Male & $22 / 32$ & $9 / 15$ \\
$\quad$ Female & $10 / 32$ & $6 / 15$ \\
Smoking & & \\
$\quad$ Yes & $20 / 32$ & $9 / 15$ \\
$\quad$ No & $12 / 32$ & $6 / 15$ \\
\hline
\end{tabular}

Table 2. Results of pulmonary function tests and arterial blood gas analysis and concentrations of thyroid hormone (mean \pm SD) in patients with COPD and controls

\begin{tabular}{|c|c|c|c|}
\hline Parameters & Patients & Controls & $\mathrm{p}$ \\
\hline $\mathrm{VC}^{\mathrm{a}}$ & $73.5 \pm 21.5$ & $99.5 \pm 9.5$ & $<0.001$ \\
\hline $\mathrm{FVC}^{\mathrm{a}}$ & $58.3 \pm 18.6$ & $94.8 \pm 11.7$ & $<0.001$ \\
\hline $\mathrm{FEV}_{1}^{\mathrm{a}}$ & $47.2 \pm 17.4$ & $97.0 \pm 10.5$ & $<0.001$ \\
\hline$P E F^{a}$ & $41.8 \pm 17.5$ & $86.5 \pm 13.2$ & $<0.001$ \\
\hline $\mathrm{PaO}_{2}, \mathrm{~mm} \mathrm{Hg}$ & $76.9 \pm 9.3$ & $93.5 \pm 2.7$ & $<0.001$ \\
\hline $\mathrm{PaCO}_{2}, \mathrm{~mm} \mathrm{Hg}$ & $36.1 \pm 6.12$ & $33.9 \pm 1.1$ & 0.016 \\
\hline $\mathrm{TSH}, \mu \mathrm{IU} / \mathrm{ml}$ & $1.4 \pm 1.0$ & $1.2 \pm 0.7$ & 0.203 \\
\hline $\mathrm{fT}_{3}, \mathrm{pg} / \mathrm{ml}$ & $3.1 \pm 0.4$ & $2.4 \pm 0.5$ & $<0.001$ \\
\hline $\mathrm{fT}_{4}, \mathrm{ng} / \mathrm{dl}$ & $1.0 \pm 0.2$ & $1.1 \pm 0.2$ & 0.399 \\
\hline
\end{tabular}

a $\quad$ Predicted $\%$.

\section{Results}

No difference was seen between the study and control groups with respect to age, gender and smoking status (table 1). The values of the pulmonary function tests (VC, FVC, $\mathrm{FEV}_{1}$ and $\mathrm{PEF}$ ) and $\mathrm{PaO}_{2}$ were lower in the study than in the control group ( $\mathrm{p} \leq 0.01$ ), but the value of $\mathrm{PaCO}_{2}$ and the concentration of $\mathrm{fT}_{3}$ were higher in the study group than controls $(\mathrm{p}<0.001$, table 2$)$. There was no statistical difference between TSH and $\mathrm{fT}_{4}$. Hormone concentrations were within normal limits in all cases.

Duration of COPD and arterial blood gas analysis were not significantly related to thyroid hormone concentrations. The values of $\mathrm{PaCO}_{2}$ and $\mathrm{fT}_{3}$ were positively associated while all other values $\left(\mathrm{VC}, \mathrm{FVC}, \mathrm{FEV}_{1}, \mathrm{PEF}\right.$ and $\mathrm{PaO}_{2}$ ) were negatively correlated with $\mathrm{fT}_{3}$ (table 2 ). In the control group, there was no correlation between thyroid hormone concentration and pulmonary function tests or arterial blood gas analysis. 


\section{Discussion}

In the patients with COPD in this study, a positive association was found between $\mathrm{PaCO}_{2}$ and $\mathrm{fT}_{3}$, and no association between TSH and $\mathrm{fT}_{4}$ on the one hand and pulmonary function tests and arterial blood gases on the other. These findings are not consistent with previous reports [4, 7-9]. Gow et al. [4] did not find any correlation between arterial blood gas measurements and thyroid hormone concentrations in patients with COPD. Pechatnikov [7], who found that $T_{3}$ and $T_{4}$ concentrations were low and TSH concentrations were high in patients with COPD, suggested that this occurred probably as a result of a compensatory (secondary) mechanism. Dimopoulou et al. [8] reported that there was a strong positive correlation between total $\mathrm{T}_{3}$ /total $\mathrm{T}_{4}$ ratio and $\mathrm{PaO}_{2}$, and that severity of the disease through hypoxemia was important in determining the peripheral metabolism of thyroid hormones. However, Banks and Cooper [9] found no relationship between hormonal levels and lung function in patients with chronic lung disease, and they suggested that most of endocrine dysfunction ascribed to COPD was probably due to factors other than hypoxia or hypercapnia. Unfortunately we are not able to explain the dissimilar results of the studies, which may possibly be due to the small number of cases. However, we suggest that due to limited airflow, increased workload of respiratory muscles affects concentrations of thyroid hormone in patients with COPD.

In this study, a negative association was found between pulmonary function tests and $\mathrm{PaO}_{2}$ on the one hand and $\mathrm{fT}_{3}$ on the other: while values of pulmonary function tests and $\mathrm{PaO}_{2}$ decreased, the concentration of $\mathrm{fT}_{3}$ increased. We did not observe any effect of theophylline on TSH and $\mathrm{fT}_{4}$, because their concentrations were the same in patients and control groups (table 2). However, other studies have reported an association between the levels of theophylline and TSH [10-12]: as concentrations of theophylline increased, concentrations of $\mathrm{TSH}$ and $\mathrm{fT}_{4}$ also increased.

\section{Conclusion}

Changes in pulmonary function tests and arterial blood gases seem to be associated with $\mathrm{fT}_{3}$ concentrations in patients with COPD, perhaps due to increased respiratory workload.

\section{References}

1 World Health Organization: World Health Report. Geneva, World Health Organization, 2000.

2 Beers MH, Berkow R: The Merck Manuel, ed 17. Whitehouse Station, Merck, 1999, p 575.

3 Bratel T, Wennlund A, Carlstrom K: Impact of hypoxaemia on neuroendocrine function and catecholamine secretion in chronic obstructive pulmonary disease (COPD): Effects of longterm oxygen treatment. Respir Med 2000;94: 1221-1228

4 Gow SM, Seth J, Beckett GJ, Douglas G: Thyroid function and endocrine abnormalities in elderly patients with severe chronic obstructive lung disease. Thorax 1987;42:520-525.

5 Semple PD, Beastall GH, Watson WS, Hume $\mathrm{R}$ : Hypothalamic-pituitary dysfunction in respiratory hypoxia. Thorax 1981;36:605-609.
6 Global Strategy for the Diagnosis, Management, and Prevention of Chronic Obstructive Pulmonary Disease. NHLBI/WHO Workshop Rep. National Heart, Lung, and Blood Institute, Publ No 2701, 2001, p 7.

7 Pechatnikov LM: Significance of hypophyseothyroid disorders in chronic obstructive bronchitis. Klin Med (Mosk) 1989;67:40-43.

8 Dimopoulou I, Ilias I, Mastorakos G, Mantzos E, Roussos C, Koutras DA: Effects of severity of chronic obstructive pulmonary disease on thyroid function. Metabolism 2001;50:13971401 .
9 Banks WA, Cooper JA: Hypoxia and hypercarbia of chronic lung disease: Minimal effects on anterior pituitary function. South Med J 1990; 83:290-293.

10 Hikita T, Fukutani K, Yamamoto Y, Yoshimizu N, Sasaki T: Effect of aminophylline injection on the pituitary-thyroid axis in asthmatics. Jpn J Med 1989;28:303-308.

11 Fukutani K: Effects of long-term administration of theophylline on the pituitary-thyroid axis in asthmatics. Arerugi 1991;40:11761185.

12 Hiritani M, Muto K, Oshida Y, Ito S, Kasei M, Ueda S, Sato T: Effect of sustained-release theophylline administration on pituitary-thyroid axis. J Allergy Clin Immunol 1982;70:481485. 